\title{
Application of the Waterfall Method on a Web-Based Job Training Management Information System at Trunojoyo University Madura
}

\author{
*Sri Herawati, Yudha Dwi Putra Negara, Husnul Fuadi Febriansyah and Doni Abdul Fatah \\ Informatic Engineering Department, University of Trunojoyo Madura, Indonesia
}

\begin{abstract}
With the development of information technology, practical work at Trunojoyo University Madura needs improvement in applied management. Practical work is a mandatory activity for Information Systems undergraduate students which aims to test and apply theory as well as scientific proof of the courses that have been obtained. In the practical work management process is still done manually, it will take up a lot of time and frequent errors. Therefore, the Job Training Management Information System will be implemented using the waterfall model, the PHP programming language with Codeingniter as its framework. The waterfall model provides a sequential approach to software life phases starting from analysis, design, code implementation, testing, and maintenance. This research produces the results of the analysis of hardware and software requirements. The design produces Use case diagrams and Entity Diagrams. Testing produces a system by testing with black box testing with valid test results. This research produces a management system that is used to manage data related to practical work activities.
\end{abstract}

Keywords: Waterfall Method, Practical Work, Management Information System

\section{Introduction}

In the world of education, computer-based information technology is currently very developed and is starting to feel its influence in the distribution of certain information[1]-[4]. But it turns out that in practice there are still many organizations that have not utilized the technology according to its purpose. One example in the Information Systems Study Program (Prodi) of Trunojoyo Madura University, this study program has practical work activities that must be carried out by students.[5].

Practical work is a course in the information systems study program at Trunojoyo Madura University which helps students get to know their field of work. In this activity, there is a lot of information needed by both students, practical work supervisors and the study program admin itself, such as information on practical work implementation schedules, practical work title information, supervisor information, student guidance information, final practical work reports etc. However, on practical work data processing, the available information is still very limited because the archiving is not well structured so that the data is not archived properly every year. In addition, submissions to carry out practical work activities are still done manually so that it wastes time but it is also prone to data loss in these activities.
One way to overcome the above problems is to need an information system that can make it easier to manage data and submit practical work[6]. Therefore, a webbased Job Training Management Information System will be created using the Codeigniter framework[7][10].

\section{Literature Review}

In developing an information system, a system development methodology is needed. The methodology that is often used is SDLC[11]-[15]. SDLC has several models that are often used in previous studies. One of them is the waterfall model. The waterfall model is used because the waterfall model is suitable for making systems that have a clear flow.

Previous research developed a system using the waterfall method [16]-[20]. From the results of several previous studies using the waterfall method, they are able to develop information systems that can be applied because they have been tested and have valid results. Previous research mentions the SDLC Waterfall model which is commonly called the classical life cycle or linear sequential model.[21]. The model is the result of adjustments from hardware development, because at that time there was no other software development methodology. This highly structured development can

\footnotetext{
* Corresponding author : sriherawati@trunojoyo.ac.id
} 
reduce the losses due to errors in previous phases which are very large and often expensive due to the increasing costs of redevelopment [22]. The waterfall model provides a sequential approach to software life phases starting from analysis, design, code implementation, testing, and maintenance. The waterfall method can be explained in Figure 1.

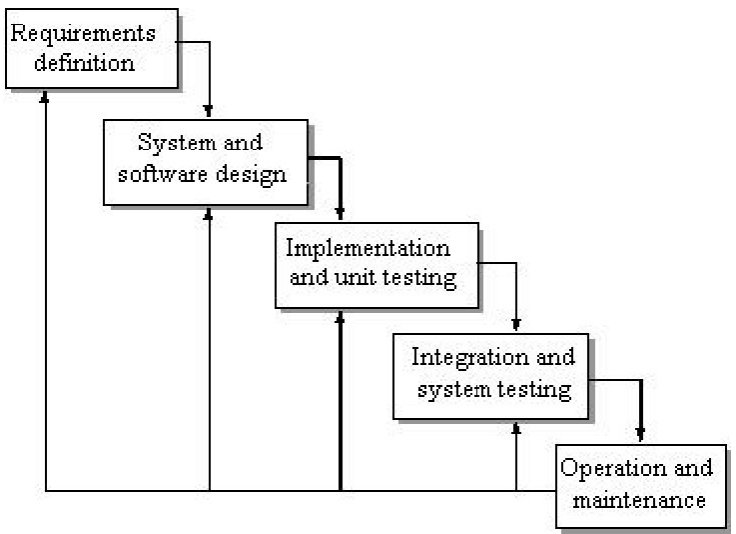

Fig. 2. Stages of the Waterfall Method.

From the comparison of models between Waterfall, Prototype and RAD Waterfall development model is suitable for systems or software that is generic, meaning that the system can identify all its needs from the start with general specifications and is suitable for software that has the goal of building a system from scratch collect system requirements to be built according to the chosen research topic until the product is tested[23].

\section{Method}

In research on the implementation of the Waterfall Method in Web-Based Job Training Management Information Systems, this research uses field research methods, literature studies and interviews. While the development of the software system used to use the waterfall model. Waterfall Model is one of the Software Development Life Cycle (SDLC) models which consists of stages of requirements analysis, design, implementation, testing and maintenance sequentially so that the development process will not proceed to the next stage if the previous phase has not been completed[24]. The stages of the waterfall method are as follows [25]:

\subsection{Requirements Definition}

Requirements Definition is the process of gathering requirements intensively to specify hardware and software requirements, so that users can understand what kind of software is required by the user. Software requirements specifications at this stage need to be documented.

\subsection{System and Software Design}

System and Software Design is a multi-step process that focuses on the design of a software program including data structures, software architecture, interface representation, and coding procedures. This stage translates software requirements from the requirements analysis stage to the design representation so that it can be implemented into a program at a later stage. The software design produced at this stage also needs to be documented.

\subsection{Implementation and unit testing}

Implementation and unit testing, the design program must be translated into software programs. The result of this stage is a computer program in accordance with the design that has been made at the design stage. Testing, testing focuses on the software logically and functionally and ensures that all parts have been tested. This is done to minimize errors and ensure that the output produced is as desired.

\subsection{Integration and system testing}

System integration testing is a test that is at the second level after unit testing.

\subsection{Operation and maintenance}

In the last stage in the Waterfall Method, the finished software is operated by the user and carried out maintenance. Maintenance allows developers to make improvements to errors that were not detected in the earlier stages. Maintenance includes repairing errors, improving the implementation of the system unit, and upgrading and adjusting the system as needed.

\section{Result}

In Web-Based Job Training Management Information System, using the waterfall method in developing the software. Then the steps or stages that must be carried out are as follows:

\subsection{Requirements Definition}

In this chapter, the results of the analysis along with the system design that have been made from the modeling results and also from the research data obtained will be explained.

\subsubsection{Hardware Requirements}

The hardware used by users to create and test websites is a laptop with the following specifications:

1. Operating System: Windows 10.

2. Processor: AMD A4-5000 APU with Radeon (TM) $1.5 \mathrm{Ghz}$

3. Memory: 4GB.

\subsubsection{Software Requirements}

The software or software that must be prepared to make this website include the following: 
1. Sublime Text 3 , which is a text editor that is used to write program codes in making websites.

2. Xampp, which is an apache webserver in which MYSQL is embedded which is supported by PHP programming to create dynamic websites.

3. Opera, which is a browser that is used to test program codes that have been written in a text editor and then displayed in the browser.

\subsection{System Design}

The software design of the Job Training Management Information System there are several types of designs, including the design of use case diagrams and database design.

\subsubsection{Use Case Diagram Design}

Use case diagrams explain the relationship or interaction between use cases and actors. Use case diagram of the information system to be built can be seen in Figure 2 .

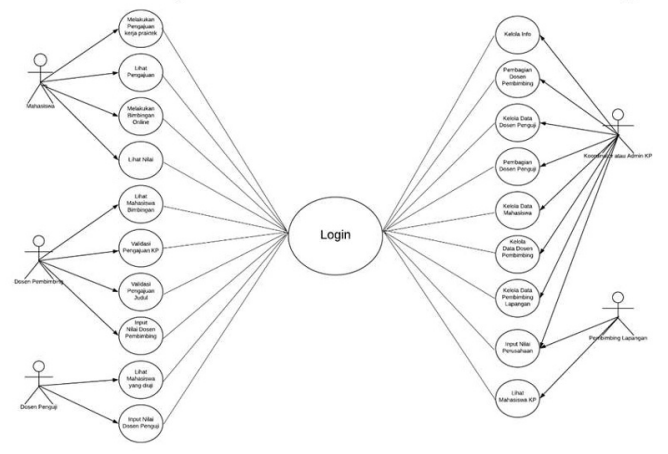

Fig. 2. Use Case Diagram Design.

\subsubsection{Database Design}

PDM (Physical Data Model) is a detailed description of the database in physical form. The depiction of the PDM design shows the correct data storage structure in the actual used database which can be seen in Figure 3.

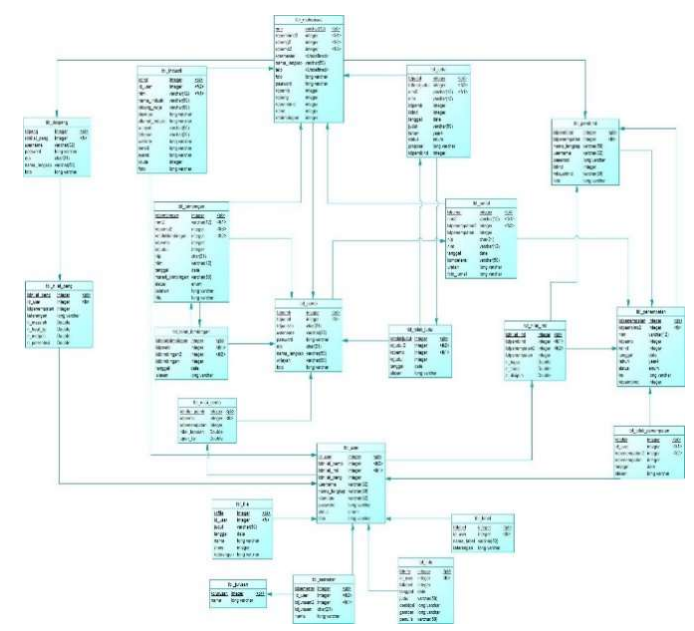

Fig. 3. Database Design

\subsection{Implementation}

The implementation of the system to be built is based on the results of the system analysis and the variety to be built. Here are some menu layouts made on the WebBased Job Training Management Information System.

\subsubsection{Homepage}

The home page or landing page contains an explanation of the application, information, industry information and a button to login to the user page.

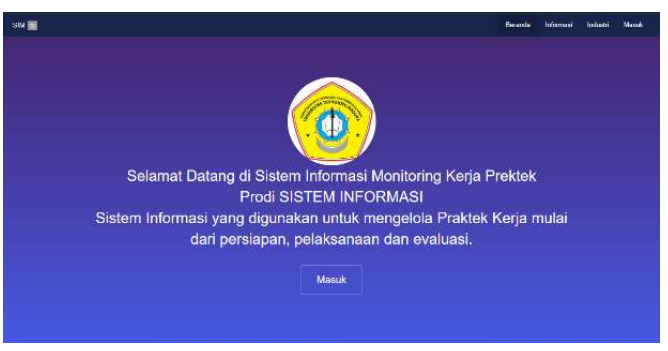

Fig. 4. Home Page View

\subsubsection{Information Page}

The information page contains information about practical work and can be accessed by non-users.

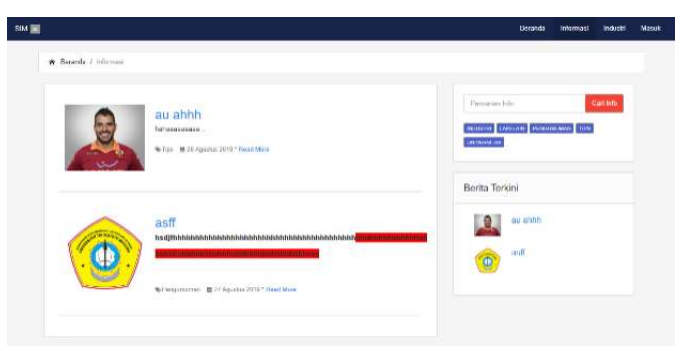

Fig. 5. Information Page Display

\subsubsection{Industrial Pages}

The industrial page contains data on industrial places that can be occupied to do practical work and can be accessed by non-users in figure 6 .

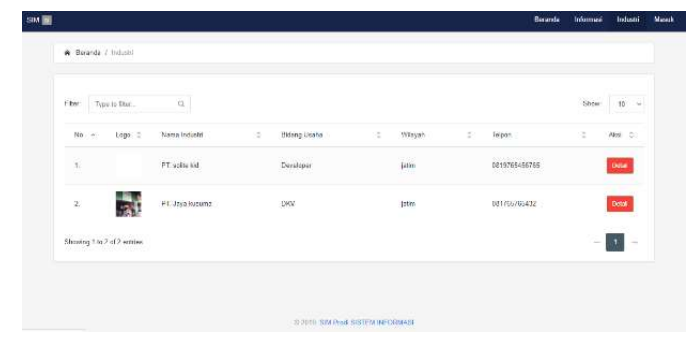

Fig. 6. Industrial Page Display 


\subsubsection{User Login}

The User Login page is used to access the user page according to the registered user in figure 7.

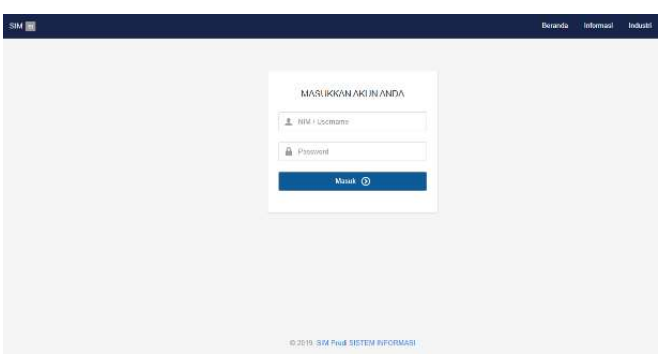

Fig. 7. User Login Display

\subsection{System Test}

This test is carried out to find out the results of the design on this Job Training Management Information System has been going well or not, it also functions to find out the shortcomings in the system that has been made. In table 1 the test results show valid results.

Table 1. System Test.

\begin{tabular}{|c|c|c|c|c|}
\hline $\begin{array}{l}\mathbf{N} \\
\text { o. }\end{array}$ & $\begin{array}{c}\text { Test } \\
\text { Items }\end{array}$ & $\begin{array}{c}\text { Test } \\
\text { Scenario }\end{array}$ & $\begin{array}{l}\text { Expected } \\
\text { results }\end{array}$ & $\begin{array}{c}\text { Test } \\
\text { result }\end{array}$ \\
\hline \multirow[t]{2}{*}{1.} & $\begin{array}{l}\text { Login } \\
\text { form }\end{array}$ & $\begin{array}{l}\text { Enter the } \\
\text { correct } \\
\text { username } \\
\text { and } \\
\text { password }\end{array}$ & $\begin{array}{l}\text { Then it will } \\
\text { go to the } \\
\text { main page }\end{array}$ & $\begin{array}{c}{[\sqrt{ }]} \\
\text { Succeed } \\
\text { [ ] Fail }\end{array}$ \\
\hline & & $\begin{array}{l}\text { Enter the } \\
\text { correct } \\
\text { username } \\
\text { and } \\
\text { password }\end{array}$ & $\begin{array}{l}\text { The } \\
\text { username and } \\
\text { password you } \\
\text { have entered } \\
\text { are incorrect }\end{array}$ & $\begin{array}{c}{[\sqrt{ }]} \\
\text { Succeed } \\
\text { [ ] Fail }\end{array}$ \\
\hline 2. & $\begin{array}{c}\text { Informatio } \\
\text { n Manage } \\
\text { Form }\end{array}$ & $\begin{array}{c}\text { Create, } \\
\text { Update, } \\
\text { Delete } \\
\text { data info }\end{array}$ & $\begin{array}{l}\text { System } \\
\text { capable of } \\
\text { running } \\
\text { CRUD }\end{array}$ & $\begin{array}{c}{[\sqrt{ }]} \\
\text { Succeed } \\
\text { [ ] Fail }\end{array}$ \\
\hline 3. & $\begin{array}{l}\text { User } \\
\text { Manage } \\
\text { Form }\end{array}$ & $\begin{array}{c}\text { Input } \\
\text { data for } \\
\text { superviso } \\
\text { ns, } \\
\text { examiner } \\
\text {, } \\
\text { students. }\end{array}$ & $\begin{array}{c}\text { The system } \\
\text { can input a } \\
\text { new user and } \\
\text { display it }\end{array}$ & $\begin{array}{c}{[\sqrt{ }]} \\
\text { Succeed } \\
\text { [] Fail }\end{array}$ \\
\hline 4. & $\begin{array}{l}\text { KP Place } \\
\text { Form }\end{array}$ & $\begin{array}{c}\text { Input } \\
\text { data for } \\
\mathrm{KP} \text { and } \\
\text { field } \\
\text { superviso } \\
\text { rs }\end{array}$ & $\begin{array}{c}\text { The system } \\
\text { can input data } \\
\text { on the } \\
\text { location of } \\
\text { the KP and } \\
\text { the field } \\
\text { supervisor }\end{array}$ & $\begin{array}{c}{[\sqrt{ }] \text { Succee }} \\
\text { d } \\
{[] \text { Fail }}\end{array}$ \\
\hline \multirow[t]{2}{*}{5.} & $\begin{array}{c}\text { Form } \\
\text { Nilai KP }\end{array}$ & $\begin{array}{c}\text { Input KP } \\
\text { value(ad } \\
\text { min) }\end{array}$ & $\begin{array}{l}\text { The system } \\
\text { can input the } \\
\text { KP value } \\
\text { along with } \\
\text { displaying } \\
\text { the value in } \\
\text { the form of } \\
\text { an average }\end{array}$ & $\begin{array}{c}{[\sqrt{ }] \text { Succee }} \\
d \\
{[] \text { Fail }}\end{array}$ \\
\hline & & $\begin{array}{c}\text { Input } \\
\text { nilai KP }\end{array}$ & $\begin{array}{l}\text { The system } \\
\text { can input the }\end{array}$ & $\begin{array}{c}{[\sqrt{ }] \text { Succee }} \\
d\end{array}$ \\
\hline
\end{tabular}

\begin{tabular}{|c|c|c|c|c|}
\hline $\begin{array}{l}\mathbf{N} \\
\text { o. }\end{array}$ & $\begin{array}{c}\text { Test } \\
\text { Items }\end{array}$ & $\begin{array}{c}\text { Test } \\
\text { Scenario }\end{array}$ & $\begin{array}{l}\text { Expected } \\
\text { results }\end{array}$ & $\begin{array}{l}\text { Test } \\
\text { result }\end{array}$ \\
\hline & & $\begin{array}{c}\text { (dosen } \\
\text { pembimb } \\
\text { ing) }\end{array}$ & $\begin{array}{l}\text { KP value } \\
\text { along with } \\
\text { displaying } \\
\text { the value in } \\
\text { the form of } \\
\text { an average }\end{array}$ & [ ] Fail \\
\hline & & $\begin{array}{c}\text { Displayin } \\
\text { g KP } \\
\text { Nilai }\end{array}$ & $\begin{array}{l}\text { The system is } \\
\text { able to } \\
\text { display the } \\
\text { student's final } \\
\text { KP score }\end{array}$ & $\begin{array}{c}\sqrt{ }] \text { Succee } \\
\text { d } \\
\text { [ ] Fail }\end{array}$ \\
\hline 6. & $\begin{array}{l}\text { Company } \\
\text { Value } \\
\text { Form }\end{array}$ & $\begin{array}{l}\text { Enter } \\
\text { company } \\
\text { value }\end{array}$ & $\begin{array}{l}\text { The system } \\
\text { can input the } \\
\text { KP value of } \\
\text { the company }\end{array}$ & $\begin{array}{c}{[\sqrt{ }]} \\
\text { Succeed } \\
\text { [ ] Fail }\end{array}$ \\
\hline 7. & $\begin{array}{l}\text { Student } \\
\text { Registrati } \\
\text { on Form }\end{array}$ & $\begin{array}{l}\text { Show } \\
\text { student } \\
\text { data }\end{array}$ & $\begin{array}{l}\text { The system is } \\
\text { able to } \\
\text { display } \\
\text { student data } \\
\text { (field } \\
\text { supervisor) }\end{array}$ & $\begin{array}{c}{[\sqrt{ }]} \\
\text { Succeed } \\
\text { [ ] Fail }\end{array}$ \\
\hline & & $\begin{array}{c}\text { Displayin } \\
\text { g student } \\
\text { data on } \\
\text { the test }\end{array}$ & $\begin{array}{l}\text { The system is } \\
\text { able to } \\
\text { display } \\
\text { student data } \\
\text { (examiner } \\
\text { lecturer) }\end{array}$ & $\begin{array}{c}{[\sqrt{ }]} \\
\text { Succeed } \\
\text { [ ] Fail }\end{array}$ \\
\hline & & $\begin{array}{l}\text { Displayin } \\
\text { g student } \\
\text { guidance } \\
\text { data }\end{array}$ & $\begin{array}{l}\text { The system is } \\
\text { able to } \\
\text { display } \\
\text { student data } \\
\text { (supervising } \\
\text { lecturers) }\end{array}$ & $\begin{array}{c}{[\sqrt{ }]} \\
\text { Succeed } \\
\text { [ ] Fail }\end{array}$ \\
\hline 8. & $\begin{array}{l}\text { Status } \\
\text { Form }\end{array}$ & $\begin{array}{l}\text { Displays } \\
\text { the status } \\
\text { of the KP } \\
\text { place }\end{array}$ & $\begin{array}{l}\text { The system is } \\
\text { able to } \\
\text { display the } \\
\text { status of the } \\
\text { student's KP } \\
\text { location, } \\
\text { accepted or } \\
\text { rejected }\end{array}$ & $\begin{array}{c}{[\sqrt{ }]} \\
\text { Succeed } \\
\text { [ ] Fail }\end{array}$ \\
\hline 9. & $\begin{array}{l}\text { KP Title } \\
\text { Form }\end{array}$ & $\begin{array}{l}\text { Upload } \\
\text { the title } \\
\text { KP }\end{array}$ & $\begin{array}{l}\text { The system is } \\
\text { able to } \\
\text { upload KP } \\
\text { titles }\end{array}$ & $\begin{array}{c}{[\sqrt{ }]} \\
\text { Succeed } \\
\text { [ ] Fail }\end{array}$ \\
\hline 10 & $\begin{array}{c}\text { Journal } \\
\text { Form }\end{array}$ & $\begin{array}{l}\text { Journal } \\
\text { upload }\end{array}$ & $\begin{array}{c}\text { The system is } \\
\text { able to } \\
\text { upload } \\
\text { journals }\end{array}$ & $\begin{array}{c}{[\sqrt{ }]} \\
\text { Succeed } \\
\text { [ ] Fail }\end{array}$ \\
\hline 11 & $\begin{array}{c}\text { KP } \\
\text { Validation } \\
\text { Form }\end{array}$ & $\begin{array}{c}\text { KP } \\
\text { submissi } \\
\text { on } \\
\text { validatio } \\
n\end{array}$ & $\begin{array}{l}\text { The system is } \\
\text { able to accept } \\
\text { / reject KP } \\
\text { applications }\end{array}$ & $\begin{array}{c}{[\sqrt{ }]} \\
\text { Succeed } \\
\text { [ ] Fail }\end{array}$ \\
\hline 12 & $\begin{array}{c}\text { Title } \\
\text { Validation } \\
\text { Form }\end{array}$ & $\begin{array}{l}\text { Validatio } \\
\mathrm{n} \text { of title } \\
\text { submissi } \\
\text { on }\end{array}$ & $\begin{array}{l}\text { The system is } \\
\text { able to } \\
\text { accept/reject } \\
\text { title } \\
\text { submissions }\end{array}$ & $\begin{array}{c}{[\sqrt{ }]} \\
\text { Succeed } \\
{[] \text { Fail }}\end{array}$ \\
\hline \multirow[t]{2}{*}{$\begin{array}{c}13 \\
.\end{array}$} & $\begin{array}{l}\text { Guidance } \\
\text { Form }\end{array}$ & $\begin{array}{l}\text { Apply for } \\
\text { guidance }\end{array}$ & $\begin{array}{l}\text { The system is } \\
\text { able to } \\
\text { upload } \\
\text { guidance files }\end{array}$ & $\begin{array}{c}{[\sqrt{ }]} \\
\text { Succeed } \\
\text { [ ] Fail }\end{array}$ \\
\hline & & $\begin{array}{c}\text { Guidance } \\
\text { validatio } \\
n\end{array}$ & $\begin{array}{l}\text { The system is } \\
\text { able to accept } \\
\text { / reject the } \\
\text { guidance file }\end{array}$ & $\begin{array}{c}{[\sqrt{ }]} \\
\text { Succeed } \\
{[] \text { Fail }}\end{array}$ \\
\hline
\end{tabular}




\section{Conclusion}

From the making of this practical work information system, it can be concluded that an application with a simple appearance has been made with the aim of facilitating practical work management so that with this application the process of doing practical work becomes more effective and efficient. In addition, the system has been tested with 13 tests using black cox testing and has valid results. The advice that can be given for the development of this system is that the system is still not integrated with the academic system, so it can be developed again by integrating it with the campus academic system.

\section{References}

[1] A. A. Abdullayev, "Cluster method in the development of critical thinking technology in the lessons in primary school," Sci. world, vol. 5, no. 81, pp. 16-19, (2020).

[2] N. P. Gordon and E. Crouch, "Digital information technology use and patient preferences for internet-based health education modalities: CrossSectional survey study of middle-aged and older adults with chronic health conditions," JMIR Aging, vol. 2, no. 1, (2019), doi: 10.2196/12243.

[3] S. Africa, "Basic Formal Education Quality, Information Technology and Inclusive Human Development in Sub-Saharan Africa," 2018.

[4] K. Ratheeswari, "Information Communication Technology in Education," J. Appl. Adv. Res., vol. 3, pp. S45-S47, (2018), doi: 10.21839/jaar.2018.v3is1.169.

[5] E. Y. Wijaya, N. Aini, P. P. Informatika, U. T. Madura, and K. Kerja, "PERCEPTIONS OF STUDENTS' WORK READYNESS AFTER IMPLEMENTING INDUSTRIAL PRACTICE WORK (KPI) IN PRODI," vol. 7, no. 2, (2021).

[6] A. F. O. Pasaribu, D. Darwis, A. Irawan, and A. Surahman, "Geographic Information System for Searching Car Workshop Locations in Bandar Lampung City Area," J. Tekno Kompak, vol. 13, no. 2, p. 1, (2019), doi: 10.33365/jtk.v13i2.323.

[7] S. C. Wibawa et al., "Online test application development using framework CodeIgniter," IOP Conf. Ser. Mater. Sci. Eng., vol. 296, no. 1, (2018), doi: 10.1088/1757-899X/296/1/012041.

[8] U. Hasanah and C. Latiffani, "International Conference on Social, Sciences and Information Technology," vol. 4509, no. 1, pp. 1-7, (2020).

[9] A. Subari, S. Manan, and E. Ariyanto, "Design of E-office system in vocational school Diponegoro University using code igniter framework," IOP Conf. Ser. Mater. Sci. Eng., vol. 801, no. 1, (2020), doi: 10.1088/1757-899X/801/1/012141.

[10] H. Ismainar, R. Melyanti, Yulisman, S. Daulay, Y. Irawan, and R. Ordila, "Management Information System for Lancang Kuning Hospital Dompet Dhuafa Pekanbaru Using Codeigniter Framework," J. Phys. Conf. Ser., vol. 1845, no. 1, (2021), doi:10.1088/1742-6596/1845/1/012031.
[11] P. Kustanto, R. W. P. Pamungkas, and A. Fathurrozi, "Development of Higher Education EInternship Applications by Utilizing SDLC SCRUM in Agile Project Management," vol. 2, no. 12, pp. 99-112, (2021).

[12] E. B. Kristanto, S. Andrayana, U. Nasional, K. J. Selatan, and L. Review, "Application of Waterfall SDLC Method in Designing Student's Web Blog Information System at the National University," vol. 4, no. 1, pp. 472-482, (2020).

[13] V. N. May, "Mysql Database Processing Information System Using The System Development Life Cycle (SDLC) Method At Quality Guarantee Agency Working Unit At National University," vol. 4, no. 1, pp. 392-398, (2020).

[14] C. Series, "Developing Framework for Web Based e-Commerce : Secure-," (2020), doi: 10.1088/1742-6596/1566/1/012020.

[15] O. J. Okesola, A. A. Adebiyi, A. A. Owoade, O. Adeaga, O. Adeyemi, and I. Odun-ayo, Software Requirement in Iterative SDLC Model Software Requirement in Iterative SDLC Model, no. November. Springer International Publishing, (2020).

[16] E. Pawan, R. H. . Thamrin, P. Hasan, S. H. Y. Bei, and P. Matu, "Using Waterfall Method to Design Information System of SPMI STIMIK Sepuluh Nopember Jayapura," Int. J. Comput. Inf. Syst., vol. 2, no. 2, pp. 33-38, (2021), doi: 10.29040/ijcis.v2i2.29.

[17] W. W. Widiyanto and S. Wulandari, "Accuracy Implementation of Medical Record Management Information System with Waterfall Design System and ISO 9126," Asian J. Res. Comput. Sci., vol. 6, no. 2, pp. 36-45, (2020), doi: 10.9734/ajrcos/2020/v6i230156.

[18] Indarti, D. Laraswati, and A. Supriyatna, "Use of waterfall model in application design web-based maryam department store," vol. 4, no. 1, pp. 3747, (2021), doi: 10.36378/jtos.v4i1.1364.

[19] T. K. Rahayu, Susanto, and Suwarjono, "Application Report Process of Islamic School Based on Pesantren Boarding Using Waterfall Model," J. Phys. Conf. Ser., vol. 1569, no. 2, (2020), doi: 10.1088/1742-6596/1569/2/022025.

[20] N. Hidayati, "Application of Waterfall Model In Development of Work Training Acceptance System," INTENSIF, vol. 4, no. 1, (2020).

[21] F. Hidayah, R. Hartawan, and A. S. Rini, "Designing a web-based driving course participant information system for the Ar ' Rahman Jakarta driving course," vol. 1, pp. 68-72, (2021), doi: 10.52362/jmijayakarta.v1i1.416.

[22] C. Tristianto, "Penggunaan Metode Waterfall Untuk Pengembangan Sistem Monotoring Dan Evaluasi Pembangunan Pedesaan," Gooseberry, vol. XII, no. 01, pp. 41-56, (2018), doi: 10.5749/j.cttttv6b.5.

[23] B. Indonesia, "Survey Paper: Comparison of Software Development Methods," vol. X, no. 01, pp. 6-12, (2021).

[24] F. Ilmu and K. Universitas, "Development of 
Management Information System Reporting Facilities and Infrastructure Development of Management Information System Reporting Study Facilities and Infrastructure at the Faculty of Computer Science Universitas Brawijaya," no. November, (2018).

[25] A. N. Mariana, "Implementation of the Waterfall Model for the Development of the DKI Jakarta PKK Current Mail Information System," vol. 6, no. 5, pp. 453-459, (2019). 